\title{
Defiant Children: A Clinician's Manual for Assessment and Parent Training by Russell A. Barkley, M.D.
}

\author{
Stephen Zerby M.D.
}

Follow this and additional works at: https://jdc.jefferson.edu/jeffjpsychiatry

Part of the Psychiatry Commons

Let us know how access to this document benefits you

\section{Recommended Citation}

Zerby, Stephen M.D. (1998) "Defiant Children: A Clinician's Manual for Assessment and Parent Training by Russell A. Barkley, M.D.," Jefferson Journal of Psychiatry. Vol. 14 : Iss. 1 , Article 8.

DOI: https://doi.org/10.29046/JJP.014.1.007

Available at: https://jdc.jefferson.edu/jeffjpsychiatry/vol14/iss1/8

This Article is brought to you for free and open access by the Jefferson Digital Commons. The Jefferson Digital Commons is a service of Thomas Jefferson University's Center for Teaching and Learning (CTL). The Commons is a showcase for Jefferson books and journals, peer-reviewed scholarly publications, unique historical collections from the University archives, and teaching tools. The Jefferson Digital Commons allows researchers and interested readers anywhere in the world to learn about and keep up to date with Jefferson scholarship. This article has been accepted for inclusion in Jefferson Journal of Psychiatry by an authorized administrator of the Jefferson Digital Commons. For more information, please contact: JeffersonDigitalCommons@jefferson.edu. 


\title{
Book Review
}

\section{Defiant Children}

\author{
Defiant Children: \\ A Clinician's Manual for Assessment and Parent Training \\ by Russell A. Barkley, M.D. \\ Second Edition \\ New York: The Guilford Press, 1997
}

\section{Stephen Zerby, M.D.}

Defiant Children, by Russell A. Barkley, is the culmination of 20 years of clinical experience and is an effort to formalize a series of procedures for training parents in child management skills. Dr. Barkley has considerable experience in teaching mental health professionals and was encouraged by these experiences to develop a manual of his techniques. This is the second edition of his manual with improvements in additional references, assessment tools, and training sessions. The program developed out of an older "two-stage" model which focused first on teaching parents to attend positively to their children and ignore inappropriate behavior and secondly, the immediate use of time out. These principles form the core of Barkley's program and he has both expanded on the use of these procedures and added additional principles and exercises. The program consists of an evaluation period and a training period. The training period consists of ten sequential steps which include both in-session training of parents as well as handouts on the use of the methods at home with homework assignments given for the parents to complete. The target population for the program is "defiant or behavior problem children" up to the age of 12 years.

Barkley provides a wealth of detailed forms which include structured interviews, behavior rating scales, questionnaires, and self-report forms, all of which are to be used during the evaluation stage. Extensive instructions are included for all forms, including a set of information sheets for parental education about the child's evaluation. These are intended to be freely photocopied and dispensed. The second set of handouts is for use in conjunction with the training manual and one handout is provided for each of the ten steps. At each step the corresponding handout is to be distributed and discussed in detail with the parents. The handouts themselves are very complete and often give useful and clever advice. For example, suggestions given for giving positive feedback and approval to the child include actions such as giving a wink and comments like "I am very proud of you when you ...." These examples are very clear, concise, and can be very helpful to parents to help get them started in 
practicing a new, more positive approach to dealing with their child. However, the handouts do tend to be rather long and wordy and may prove intimidating to a parent with limited time or cognitive functioning. More streamlined handouts with major points or suggestions highlighted and in more of an outline form with more concrete suggestions for parents would be an improvement. Of course it is up to the therapist's discretion to use the handouts as an all-inclusive guideline which can be edited to what he or she believes is most pertinent and useful for the family. The text would be difficult to implement as a step-by-step manual and digestion, reprocessing, and reformulation by the therapist into his or her own personalized treatment, albeit based firmly in Barkley's, would be the ideal use of his manual.

Overall, the manual is filled with very useful information. Within the text can be found background material regarding the proper evaluation of children, which patients and which conditions are best suited to this program, theory of which strategies work and why they do, and very concrete plans and suggestions for treatment replete with exercises and homework assignments as well as the rationale behind them. There is a great deal of information in the manual but this also leads to some difficulties with its use as a teaching tool. Some paragraphs are too long and densely written to the point that the reader can lose track of the main point of the paragraph, which may necessitate rereading of sections. Even when at first glance the pages seem outlined and apparently easy to organize and compartmentalize the information it seems surprisingly easy to get lost while reading. Perhaps more highlighted points, subheadings, and clinical pearls might help to break the material up into more digestible portions and maximize the efficiency of learning. The handouts are in the rear of the book which can make for a mild inconvenience when referred to in the text. Another concern is the suggestion that each of the ten steps outlined in the manual can be accomplished in one session each. If a step is not mastered, it is to be repeated, but no clear guidelines to length of session or the number of repeated sessions allowed before the family fails therapy is alluded to. Perhaps there is room for the therapist to use his or her discretion and creativity to create his or her own program.

All-in-all, Barkley's Defiant Children is an impressive work that reflects years of clinical experience and provides a great deal of useful information. It can be used to guide the therapist in developing an effective program in behavioral techniques to be used by parents to deal with defiant children. Its background information and description of the rationale for the program is exhaustive. The steps involved in the training program are clearly outlined with generous support provided by detailed handouts. If carefully studied and implemented, Barkley's program appears to have the potential to be put into clear, useful clinical practice and can serve as the basis for approaching a clinic population. Therefore it is highly recommended for therapists interested in learning more about behavioral treatment of children and planning to put this knowledge into practice. 